\title{
Elucidation of Genetic Diversity as Morphological, Phytochemical and Molecular Markers in Some Hawthorn (Crataegus) Genotypes
}

\section{Ercan YILDIZ}

Erciyes Universitesi

Mehmet YAMAN

Erciyes University: Erciyes Universitesi

Ahmet SÜMBÜL ( $\sim$ asumbul3188@gmail.com )

Sivas Cumhuriyet Universitesi

Ahmet SAY

Erciyes University: Erciyes Universitesi

\section{Research Article}

Keywords: Hawthorn, ISSR, fruit, biochemical, genetic diversity

Posted Date: December 29th, 2021

DOI: https://doi.org/10.21203/rs.3.rs-1202879/v1

License: (c) (i) This work is licensed under a Creative Commons Attribution 4.0 International License.

Read Full License 


\section{Abstract \\ Backround:}

Thanks to its ecological and geographical location, Turkey is the homeland of many fruit species and allows many fruit species to be grown. Hawthorn, which is understood to be important in human health and nutrition, is one of these fruit types. This study was carried out to identify morphological, biochemical and molecular genetic variations of 22 hawthorn genotypes belonging to three different species collected from Kayseri province.

\section{Methods and Results:}

Morphological, biochemical and molecular marker (ISSR) techniques were used to determine genetic diversity. The fruit and leaf characteristics of the genotypes showed differences. Among the biochemical properties of the genotypes, the antioxidant activity ranged from $23.13-61.59 \%$, the total flavonoid content ranged from 16.63 to $57.22 \mathrm{mg} \mathrm{QE} / 100 \mathrm{~g}$, and the total phenolic content ranged from 277.28 to $310.80 \mathrm{mg} \mathrm{GAE} / 100 \mathrm{~g}$. Genotypes were compared with principal component analysis according to their morphological and biochemical characteristics. In the principal component analysis, species generally formed similar clusters. In molecular marker analysis, 101 bands were obtained from 13 ISSR primers. 76 of the bands are polymorphic and the polymorphism rate was calculated as $75.24 \%$. The similarity index in the UPGMA dendogram obtained as a result of the molecular analysis ranged between 0.71 and 0.88 . In the dendrogram, genotypes did not show a dense clustering by species.

\section{Conclusion}

The results obtained may benefit researchers in the determination and protection of gene sources in breeding studies on hawthorn species.

\section{Introduction}

Since the climate in Turkey changes from subtropical to terrestrial, most plant species grow naturally and economically throughout the country [1]. Among these plants, hawthorn (Crataegus spp.) is widely distributed in the northern hemisphere [2]. Its tree form varies from shrub to single tree form and is widely found in Western Asia, North America, and Europe [3-4]

Turkey is an important gene center for hawthorn species. It has been reported that there are 25 hawthorn species including those recently identified in Turkey [2]. Hawthorn grows naturally in mountainous areas, bushes and rocks in our country and no cultural treatment is applied to these natural plants. While the most common hawthorn species in Turkey is Crataegus monogyna, Crataegus orientalis, Crataegus oxyacantha, and Crataegus aronia species are other common species. In different regions of Turkey, it is known by local names such as "halıç, yaban gülü, haziran, yemişen, alıç, aluç and ekşi muşmula" [5-6]. 
Although the hawthorn has many different uses, it has not found enough interest compared to other fruit species. Hawthorn is used as an ornamental plant due to its plant shape and flowers, and in addition, it is generally known as a wild fruit [7]. Since ancient times, its fruits were generally collected from nature and evaluated, today there is an increasing interest in the economic cultivation of the consumer and hawthorn orchards are established in Turkey. Due to its rich phytochemical content, hawthorn fruits are among the important medicinal plants in terms of both healthy nutrition and pharmacy [8]. Considering horticultural crops, hawthorn is known that it has the potential to be used as rootstock for some important pome fruit species $([1-9]$.

With the increasing world population, unconscious use of plant resources to meet human needs, damage to the natural cover due to land expansion, urbanization and industrialization cause the decrease and rapid loss of plant gene resources. [10]. The starting point for the effective use and protection of gene resources is the detection of genetic variation [11]. Thus, rather than those that are closely related to each other, those with a wide variety should be preferred. Morphological, molecular, phenological and phytochemical marker systems have been used for years to determine genetic diversity among plants, including hawthorn [12-13-14-15-16-17-18]. Among these marker systems, molecular techniques without the effect of environmental conditions give more precise results than others [19]. Since some features that play a role in resistance to abiotic and biotic conditions in plants are controlled by multiple genes [20], studies that combine molecular, phytochemical, and morphological markers are needed for the determination, protection, and sustainability of plant genetic diversity.

In this study, it was aimed to determine genetic variation in 22 hawthorn genotypes, which stand out in terms of different characteristics such as shape and size, in Kayseri province, by ISSR molecular marker technique, phytochemical, leaf and fruit characteristics.

\section{Material And Method}

\section{Material}

In the study, 22 different hawthorn genotypes (belonging to 3 different species) differing from each other in parameters such as fruit weight, fruit shape and fruit color were used as plant material. Genotypes were collected from different regions of Kayseri province located in the center of Anatolia (Table 1). In terms of ecological conditions, Kayseri province is generally cold and snowy in winter, hot and dry in summer, and has a soil structure that is poor in organic matter and poor water holding capacity in terms of soil characteristics (Figure 1). 
Table 1

Species name, coordinate, and altitude information of hawthorn genotypes

\begin{tabular}{|c|c|c|c|}
\hline Gen. & Species Name & Coordinate & Attitue \\
\hline G1 & Crataegus azarolus L. var. azarolus & $38^{\square} 39 \rrbracket 56-35^{\square} 31 \rrbracket 28$ & 1277 \\
\hline $\mathrm{G} 2$ & Crataegus azarolus L. var. azarolus & $3838 \rrbracket 57-35^{\square} 31 \rrbracket 50$ & 1374 \\
\hline G3 & Crataegus azarolus L. var. azarolus & $38^{\square} 38 \rrbracket 56-35^{\square} 33 \rrbracket 11$ & 1333 \\
\hline G4 & Crataegus monogyna Jacq. var. monagyna & $38^{\square} 40 \rrbracket 04-35^{\square} 31 \rrbracket 39$ & 1261 \\
\hline G5 & Crataegus monogyna Jacq. var. monagyna & $3839 \rrbracket 44-35^{\square} 31 \rrbracket 28$ & 1289 \\
\hline G6 & Crataegus monogyna Jacq. var. monagyna & $38^{\square} 39 \rrbracket 12-35^{\square} 31 \rrbracket 34$ & 1356 \\
\hline G7 & Crataegus monogyna Jacq. var. monagyna & $38^{\square} 38 \rrbracket 58-35^{\square} 31 \rrbracket 45$ & 1383 \\
\hline G8 & Crataegus monogyna Jacq. var. monagyna & $38^{\square} 39 \rrbracket 44-35^{\square} 31 \rrbracket 28$ & 1289 \\
\hline G9 & Crataegus monogyna Jacq. var. monagyna & $3846 \rrbracket 14-35^{\square} 40 \rrbracket 33$ & 1348 \\
\hline G10 & Crataegus azarolus L. var. dentata & $38^{\square} 47 \rrbracket 04-35^{\square} 41 \rrbracket 22$ & 1318 \\
\hline G11 & Crataegus monogyna Jacq. var. monagyna & $38^{\square} 48 \rrbracket 21-35^{\square} 42 \rrbracket 34$ & 1324 \\
\hline $\mathrm{G} 12$ & Crataegus monogyna Jacq. var. monagyna & $38^{\square} 48 \rrbracket 34-35^{\square} 42 \rrbracket 40$ & 1322 \\
\hline G13 & Crataegus monogyna Jacq. var. monagyna & $38^{\square} 48 \rrbracket 46-35^{\square} 42 \rrbracket 47$ & 1304 \\
\hline G14 & Crataegus monogyna Jacq. var. monagyna & $38^{\square} 48 \rrbracket 45-35^{\square} 42 \rrbracket 59$ & 1308 \\
\hline G15 & Crataegus monogyna Jacq. var. monagyna & $38^{\square} 48 \rrbracket 10-35^{\square} 42 \rrbracket 28$ & 1323 \\
\hline G16 & Crataegus azarolus L. var. azarolus & $38^{\square} 48 \rrbracket 46-35^{\square} 43 \rrbracket 00$ & 1302 \\
\hline $\mathrm{G} 17$ & Crataegus monogyna Jacq. var. monagyna & $38^{\square} 47 \rrbracket 33-35^{\square} 43 \rrbracket 50$ & 1316 \\
\hline G18 & Crataegus azarolus L. var. dentata & $388^{\square} 48 \rrbracket 10-35^{\square} 42 \rrbracket 28$ & 1323 \\
\hline G19 & Crataegus azarolus L. var. dentata & $38^{\square} 47 \rrbracket 33-35^{\square} 43 \rrbracket 50$ & 1316 \\
\hline G20 & Crataegus azarolus L. var. dentata & $38^{\square} 40 \rrbracket 04-35^{\square} 31 \rrbracket 42$ & 1263 \\
\hline G21 & Crataegus monogyna Jacq. var. monagyna & 38 39『 $17-35^{\square} 28 \rrbracket 41$ & 1291 \\
\hline $\mathrm{G} 22$ & Crataegus azarolus L. var. azarolus & $38^{\square} 38 \rrbracket 40-35^{\square} 29 \rrbracket 15$ & 1395 \\
\hline
\end{tabular}




\section{Fruit and Leaf Characterization}

For leaf and fruit characterization of genotypes, 20 leaf and fruit samples from each genotype with 3 replicates were collected at the time of fruit ripening (end of September, beginning of October). Random leaf (middle parts of the annual shoot are preferred) and fruit samples were taken from different regions of the genotype to which these samples belong. In the leaf samples, leaf width, leaf length, petiole length, petiole thickness was measured in $\mathrm{mm}$ with the help of a digital caliper sensitive to 0.01. In fruit samples, fruit weight and stone weight $(0.01 \mathrm{~g}$ sensitive scale), fruit length $(\mathrm{mm})$, fruit width $(\mathrm{mm})$, fruit pulp/stone ratio; Flesh $/$ stone ratio $=$ (Fruit weight - stone weight $) /$ stone weight was determined. The soluble solid content was determined with the help of a hand refractometer.

\section{Phytochemical Analysis}

Phytochemical properties of hawthorn genotypes were determined with 3 replicates and 20 fruits per replicate. The stones of the fruits were removed, and the extractions were carried out by making them homogeneous with a hand blender. For this, $10 \mathrm{~g}$ of each sample was taken, and $10 \mathrm{~mL}$ of $80 \%$ methanol was added. The samples were centrifuged at $6000 \times \mathrm{g}$ for $5 \mathrm{~min}$ at $4 \circ \mathrm{C}$. Supernatant was collected and used in total phenolic, anthocyanin, flavonoid, and antioxidant assay procedures.

\section{Total monomeric anthocyanin (TMA) content}

The TMA content was measured using a spectrophotometric $\mathrm{pH}$ differential protocol [21]. Samples taken from the extractant were incubated for 2 hours in a buffer medium, then readings were taken in the spectrophotometer at 527 and $700 \mathrm{~nm}$ wavelengths. Results are given as (mg cyn-3-gluc /100 g).

\section{Total Flavonoids content}

Flavonoid contents were determined according to method reported by [22]. For this purpose, $500 \mu \mathrm{L}$ of extract was taken, $500 \mu \mathrm{L}$ of distilled water and $100 \mu \mathrm{L}$ of $5 \%$ NaNO3 were added to it and mixed for 6 minutes. waited, then $100 \mu \mathrm{L}$ of $10 \%$ AlCl3 was added. Mixing again and 6 min. After standing, $1 \mathrm{~mL}$ of $1.0 \mathrm{M} \mathrm{NaOH}$ was added, and the volume was made up to $2.5 \mathrm{~mL}$ with distilled water. Samples were read at $510 \mathrm{~nm}$ wavelength and the results were presented as $\mathrm{mg} / 100 \mathrm{~g}$ fresh weight as quercetin equivalent (QE).

\section{DPPH antioxidant activity (Free radical scavenging activity)}

Brand-Williams et al. [23]'s method was used in the determination of antioxidant activity. A 0.2 mM DPPH (1.1-diphenyl-2-picryl-hydrazil) solution was prepared for analysis. After adding $2900 \mu \mathrm{L}$ of DPPH solution to $100 \mu \mathrm{L}$ of fruit extract and mixing with vortex, the mixture was incubated for $30 \mathrm{~min}$. was incubated in the dark. Readings were made at a wavelength of $517 \mathrm{~nm}$ and results presented as \% according to Garcia et al. [24]. 
To determine the total phenolic content of the samples, Singleton et al. [25]'s Folin-Ciocalteu method was used with minor modifications. For this purpose, $200 \mu \mathrm{L}$ of extract was taken and $1800 \mu \mathrm{L}$ of distilled water and $1 \mathrm{~mL}$ of $1 / 10$ diluted Folin-Ciocalteu's solution were added, and $2 \mathrm{~mL}$ of $2 \% \mathrm{Na} 2 \mathrm{CO} 3$ was added to the samples that were mixed and kept for 5 minutes. After the thoroughly mixed samples were kept in the dark for 1 hour, the absorbance values were measured spectrophotometrically at a wavelength of 760 $\mathrm{nm}$. The results obtained were calculated in gallic acid and expressed as mg100 $\mathrm{g}$ (fresh weight).

\section{ISSR Analysis}

DNA isolation from young leaves in hawthorn genotypes was extracted according to the CTAB method [26]. DNA concentrations of genotypes were measured with a spectrophotometer (BioTek Instruments, Inc., Winooski, VT, United States) and DNAs were stored at $-20^{\circ} \mathrm{C}$. In ISSR analysis, testing was performed on 20 different primers, and band formation was observed in 13 of these primers. PCR contents $2 \mu$ DNA (20 ng), $1.5 \mu \mathrm{l}$ 10x PCR Buffer, $0.2 \mu \mathrm{l} \mathrm{Taq} \mathrm{DNA} \mathrm{polymerase} \mathrm{(} 5 \mathrm{u} / \mu \mathrm{L}), 1 \mu \mathrm{dNTP}(2.5 \mathrm{mM}), 1.5 \mu \mathrm{l} \mathrm{MgCl} 2(25 \mathrm{mM})$, $2 \mu \mathrm{l} 10 \mathrm{mM}$ ISSR primer, and $6.8 \mu \mathrm{l}$ of $\mathrm{H}_{2} \mathrm{O}$, PCR cycles were performed according to Yaman [20].

\section{Data Analysis}

Leaf and fruit samples used in morphological characterization and phytochemical properties were analyzed using SPSS 23.0 package program. Duncan multiple comparison test was used in the evaluation of the results, and the values were presented at the $5 \%$ significance level. Principal component analysis (PCA) based on morphological and biochemical data was performed with JMP pro 14 software (SAS Institute Inc., Cary, NC, USA). In ISSR analyzes, images obtained after agarose gel electrophoresis and imaging process (Kodak) were scored in the presence of band (1), if there is no band (0), and if amplification did not occur (9). The data obtained were evaluated by using the NTSYS (Version 2.11X) computer program [27]. By creating a similarity matrix with the Dice method, dendrograms were formed in hawthorn genotypes according to the UPGMA (Unweighted Pair Group Method with Arithmetic Mean of Cluster analysis) method [28]. In addition, the total number of bands, the number of polymorphic bands and the rate of polymorphism were determined for each marker used in the study. While calculating the polymorphism ratio, the formula (Number of Polymorphic Bands X 100 / Total Number of Bands) was used.

\section{Results And Discussion}

\section{Morphological Data}

In all the morphological (leaf and fruit) parameters examined in the study, wide variations occurred between genotypes, and these results were found to be statistically significant (Table 2). While the G18 genotype with $48.53 \mathrm{~mm}$ and the $\mathrm{G} 7$ genotype with $46.40 \mathrm{~mm}$ produced high results in leaf length values of the genotypes, the lowest leaf length was found in the G10 genotype with $20.93 \mathrm{~mm}$. In leaf width, the G7 genotype took the first place with $46.33 \mathrm{~mm}$, and the average leaf width of the genotypes was determined as $27.39 \mathrm{~mm}$. Leaf characteristics are among the parameters used to distinguish genotypes, and there may be differences in the results depending on the plant material used [29]. It has been reported 
that the leaf length parameter varies between $20.4 \mathrm{~mm}$ and $130.3 \mathrm{~mm}$, the leaf width parameter varies from $13.3 \mathrm{~mm}$ to $45.7 \mathrm{~mm}$, and the petiole value varies between $6.2 \mathrm{~mm}$ and $20.0 \mathrm{~mm}$ in different hawthorn genotypes [30]. Petiole length and petiole thickness values of $19.67 \mathrm{~mm}$ (G7 genotype) and 0.97 $\mathrm{mm}$ (G3 genotype), respectively, are the highest results. In the leaf parameters examined in general, the G7 genotype formed higher values compared to the other genotypes. As in our study, it has been reported in the literature that there are differences in leaf parameters between hawthorn genotypes [31].

Fruit characteristics are among the important morphological features in hawthorn as in most fruit species. Fruit length values examined in the present study differed between $10.77 \mathrm{~mm}$ (G15 genotype) and 17.32 $\mathrm{mm}$ (G3 genotype), and the average fruit length was determined as $12.88 \mathrm{~mm}$. Various studies have been carried out to determine fruit characteristics in hawthorn species. It has been reported that fruit length values in different genotypes vary between $13.00 \mathrm{~mm}$ and $18.20 \mathrm{~mm}$ in Iran [32], and between $23.90 \mathrm{~mm}$ and $27.00 \mathrm{~mm}$ in Turkey [33]. In our study, the highest fruit width was determined at $20.64 \mathrm{~mm}$ in the G3 genotype, while the lowest was $10.33 \mathrm{~mm}$ in the $\mathrm{G} 11$ genotype. In previous studies, it has been reported that the variation in fruit width values ranges from $6.56 \mathrm{~mm}$ to $20.78 \mathrm{~mm}$ [34] and $10.52 \mathrm{~mm}$ to $29.48 \mathrm{~mm}$ [35]. In the fruit weight results, while the average value of the genotypes was $1.42 \mathrm{~g}$, the highest value was $3.13 \mathrm{~g}$ and the G3 genotype formed. The most prominent genotypes compared to other genotypes in stone weight and meat core ratio were $\mathrm{G} 7$ genotype with $0.32 \mathrm{~g}$ and $\mathrm{G} 2$ genotype with 16.59 values, respectiv. In a study, it was determined that the fruit weight values ranged from $0.65 \mathrm{~g}$ to $4.19 \mathrm{~g}$ [36], and the stone weight was between 0.19-0.38 g [37]. In the current study, it was determined that the SÇKM contents of the genotypes varied between $9.00 \%$ and $18.00 \%$. In general, our findings on fruit characteristics showed similar features with the findings in the literature, as well as partial differences. The reason for this may be the different genetic material used.

Table 2. Leaf and fruit characteristics of hawthorn genotypes 


\begin{tabular}{|c|c|c|c|c|c|c|c|c|c|c|}
\hline Gen. & $\begin{array}{c}\text { L.L } \\
(\mathrm{mm})\end{array}$ & $\begin{array}{l}\text { L.W } \\
(\mathrm{mm})\end{array}$ & $\begin{array}{c}\text { P.L } \\
(\mathrm{mm})\end{array}$ & $\begin{array}{c}\text { P.T } \\
(\mathrm{mm})\end{array}$ & $\begin{array}{c}\text { F.L } \\
(\mathrm{mm})\end{array}$ & $\begin{array}{l}\text { F.WH } \\
(\mathrm{mm})\end{array}$ & $\begin{array}{l}\text { F.W } \\
(\mathrm{g})\end{array}$ & $\begin{array}{l}\text { S.W } \\
(\mathrm{g})\end{array}$ & $\begin{array}{l}\text { Flesh/ } \\
\text { Stone }\end{array}$ & SSC \\
\hline G1 & $28,43 \mathrm{de}$ & $23,87 \mathrm{gh}$ & 3,33ij & $0,57 \mathrm{bc}$ & $14,69 \mathrm{bc}$ & $18,98 \mathrm{~b}$ & $2,58 c$ & $0,18 \mathrm{e}-\mathrm{i}$ & $12,96 \mathrm{bc}$ & $13,00 \mathrm{~cd}$ \\
\hline G2 & $30,87 \mathrm{cde}$ & $37,47 a b c$ & 6,40hij & $0,90 \mathrm{a}$ & $16,00 \mathrm{~b}$ & $16,71 \mathrm{c}$ & $2,61 \mathrm{c}$ & $0,15 \mathrm{i}$ & $16,59 a$ & $11,00 \mathrm{ef}$ \\
\hline G3 & $37,43 \mathrm{bc}$ & $42,50 \mathrm{ab}$ & $7,87 j$ & $0,97 a$ & $17,32 \mathrm{a}$ & $20,64 a$ & $3,13 a$ & $0,20 d-i$ & $15,33 a b$ & $13,00 \mathrm{~cd}$ \\
\hline G4 & $34,73 \mathrm{bcd}$ & $25,10 \mathrm{e}-\mathrm{h}$ & $8,07 f-i$ & 0,47 cde & $12,27 d-j$ & $13,05 \mathrm{~h}-\mathrm{k}$ & $1,34 \mathrm{f}$ & 0,21c-i & $5,48 \mathrm{ef}$ & $14,00 \mathrm{c}$ \\
\hline G5 & $36,27 b c$ & $35,53 \mathrm{bcd}$ & $12,97 b-f$ & $0,50 \mathrm{~cd}$ & $13,45 \mathrm{~cd}$ & 13,24hij & $1,33 \mathrm{f}$ & $0,30 \mathrm{ab}$ & 3,33gh & $16,00 \mathrm{~b}$ \\
\hline G6 & $36,57 \mathrm{bc}$ & $31,03 \mathrm{c}-\mathrm{g}$ & $17,67 \mathrm{ab}$ & $0,40 \mathrm{c}-\mathrm{f}$ & $12,13 \mathrm{~d}-\mathrm{j}$ & $11,78 \mathrm{j}-\mathrm{m}$ & 1,11hi & $0,22 b-i$ & 4,17gh & $17,00 \mathrm{ab}$ \\
\hline G7 & $46,40 \mathrm{a}$ & 46,33a & $19,67 a$ & 0,47cde & $13,58 \mathrm{~cd}$ & 12,68ijk & 1,16hi & $0,32 \mathrm{a}$ & $2,64 \mathrm{gh}$ & $14,00 \mathrm{c}$ \\
\hline G8 & $25,43 \mathrm{ef}$ & 18,80hi & $11,73 \mathrm{c}-\mathrm{g}$ & $0,17 \mathrm{~g}$ & $11,65 \mathrm{e}-\mathrm{j}$ & $10,69 \mathrm{~m}$ & 0,81kl & $0,24 a-i$ & $2,51 \mathrm{gh}$ & $10,00 \mathrm{fg}$ \\
\hline G9 & $27,77 \mathrm{de}$ & $25,33 e-h$ & $13,90 \mathrm{bcd}$ & 0,47cde & $12,88 \mathrm{def}$ & 13,66ghi & $1,20 \mathrm{fg}$ & $0,30 \mathrm{abc}$ & $3,08 \mathrm{gh}$ & $14,00 \mathrm{c}$ \\
\hline G10 & $20,93 f$ & $13,07 i$ & $2,73 j$ & 0,30efg & $12,67 d-g$ & $15,03 \mathrm{def}$ & $1,74 d$ & $0,22 b-i$ & $7,12 \mathrm{e}$ & $12,00 \mathrm{de}$ \\
\hline G11 & 28,63de & 20,97hi & $9,10 \mathrm{~d}-\mathrm{h}$ & $0,40 c-f$ & $10,83 \mathrm{ij}$ & $10,33 \mathrm{~m}$ & 0,691 & $0,19 \mathrm{e}-\mathrm{i}$ & $2,75 \mathrm{gh}$ & $14,00 \mathrm{c}$ \\
\hline G12 & $28,00 \mathrm{de}$ & 19,80hi & $7,43 g-i$ & 0,30efg & $12,06 \mathrm{~d}-\mathrm{j}$ & $10,92 \mathrm{~lm}$ & 0,80kl & 0,26a-g & $2,12 \mathrm{~g}$ & $11,00 \mathrm{ef}$ \\
\hline G13 & $33,10 \mathrm{bcd}$ & $24,23 f g h$ & 13,57b-e & $0,43 c-f$ & $12,47 d-h$ & 12,49i-l & $1,02 \mathrm{ij}$ & 0,26a-g & $3,06 \mathrm{gh}$ & $12,00 \mathrm{de}$ \\
\hline G14 & $36,03 \mathrm{bc}$ & $34,10 \mathrm{~b}-\mathrm{e}$ & $16,57 \mathrm{abc}$ & 0,37def & $11,23 g-j$ & $11,89 \mathrm{j}-\mathrm{m}$ & 0,82kl & 0,28a-e & $2,04 \mathrm{~g}$ & $13,00 \mathrm{~cd}$ \\
\hline G15 & $25,33 \mathrm{ef}$ & 18,53hi & 9,63d-h & $0,27 f g$ & $10,77 j$ & $10,58 \mathrm{~m}$ & 0,79kl & $0,18 \mathrm{e}-\mathrm{i}$ & 3,58gh & $9,00 \mathrm{~g}$ \\
\hline G16 & 28,63de & 17,20hi & $8,43 e-i$ & $0,43 c-f$ & $12,90 \mathrm{def}$ & $15,40 \mathrm{cde}$ & $1,73 d$ & $0,16 f-i$ & $10,60 \mathrm{~cd}$ & $12,00 \mathrm{de}$ \\
\hline G17 & $32,20 \mathrm{~b}-\mathrm{e}$ & $33,70 b-f$ & 13,23b-e & $0,47 \mathrm{cde}$ & 11,10hij & $11,41 \mathrm{klm}$ & $0,86 \mathrm{k}$ & $0,28 a-d$ & $2,11 \mathrm{~g}$ & $13,00 \mathrm{~cd}$ \\
\hline G18 & 48,53a & $38,23 a b c$ & $19,63 a$ & $0,73 b$ & $\begin{array}{c}12,90 \\
\operatorname{def}\end{array}$ & $16,36 \mathrm{~cd}$ & 0,91jk & $0,25 a-h$ & $2,83 \mathrm{gh}$ & $9,00 \mathrm{~g}$ \\
\hline G19 & $38,90 b$ & $25,77 \mathrm{e}-\mathrm{h}$ & $6,90 \mathrm{~g}-\mathrm{i}$ & $0,50 \mathrm{~cd}$ & $12,34 d-i$ & $14,61 \mathrm{efg}$ & $1,51 \mathrm{e}$ & $0,19 d-i$ & $7,06 \mathrm{e}$ & $16,00 \mathrm{~b}$ \\
\hline G20 & $32,40 \mathrm{~b}-\mathrm{e}$ & $23,27 \mathrm{gh}$ & $7,30 \mathrm{~g}-\mathrm{i}$ & $0,57 \mathrm{bc}$ & $11,37 f-j$ & 13,60ghi & 1,05hij & $0,31 \mathrm{a}$ & $2,38 \mathrm{gh}$ & $18,00 \mathrm{a}$ \\
\hline G21 & $32,47 b-e$ & $26,53 d-h$ & $17,20 \mathrm{ab}$ & $0,27 \mathrm{fg}$ & 13,00de & $13,10 \mathrm{~h}-\mathrm{k}$ & 1,17hi & $0,27 a-f$ & 3,48gh & $14,00 \mathrm{c}$ \\
\hline G22 & $39,00 \mathrm{~b}$ & $21,27 \mathrm{hi}$ & 5,53hij & $0,53 \mathrm{~cd}$ & $15,73 \mathrm{~b}$ & $20,90 \mathrm{a}$ & $2,80 \mathrm{~b}$ & $0,31 \mathrm{a}$ & 7,97de & $14,00 \mathrm{c}$ \\
\hline Mean & 33,09 & 27,39 & 10,86 & 0,48 & 12,88 & 14,00 & 1,42 & 0,24 & 5,60 & 13,14 \\
\hline
\end{tabular}

L.L: Leaf Length, LW: Leaf Width, P.L: Petiole Length, P.T: Petiole Thickness, F.L: Fruit Length, F.WH: Fruit Width, F.W: Fruit Weight, S.W: Stone Weight, SSC: Soluble Solid Content

Different lower case letters show statistically significant differences between genotypes in column $(p<0.05$

\section{Phytochemical Data}

Phytochemicals are very important for human health. Studies have been carried out in different fruit species, especially on antioxidants, phenolics, anthocyanins and flavonoids that constitute phytochemicals. In all these traits examined in the present study, wide variations emerged between genotypes, and these results were found to be statistically significant (Table 3).

Table 3. Phytochemical characteristics in hawthorn genotypes 


\begin{tabular}{|c|c|c|c|c|}
\hline Gen. & $\begin{array}{l}\text { Antioxidant activity } \\
\text { (\% inhibition) }\end{array}$ & $\begin{array}{c}\text { Total flavonoids } \\
\text { (mg QE/100 g) }\end{array}$ & $\begin{array}{l}\text { Total phenolics } \\
(\mathrm{mg} \text { GAE } / 100 \mathrm{~g})\end{array}$ & $\begin{array}{l}\text { Total Monomeric Anthocyanin } \\
\text { (mg cyn-3-gluc /100 g) }\end{array}$ \\
\hline G1 & $51,45 \mathrm{~g}$ & $26,48 \mathrm{ij}$ & $290,26 j$ & $0,85 n$ \\
\hline $\mathrm{G} 2$ & $61,59 a$ & $36,48 \mathrm{~cd}$ & $286,74 \mathrm{k}$ & $1,42 \mathrm{k}$ \\
\hline G3 & $58,70 \mathrm{bc}$ & 35,00 de & 277,281 & $1,38 \mathrm{kl}$ \\
\hline G4 & $39,13 \mathrm{~m}$ & $20,55 \mathrm{k}$ & $302,69 \mathrm{~h}$ & $3,27 e$ \\
\hline G5 & $55,80 \mathrm{de}$ & 15,741 & $302,42 \mathrm{~h}$ & $2,84 f g$ \\
\hline G6 & $34,06 \mathrm{no}$ & 32,77 ef & $303,23 \mathrm{gh}$ & $2,95 f$ \\
\hline G7 & $53,62 f$ & $25,37 j$ & $308,91 \mathrm{ab}$ & $2,71 \mathrm{gh}$ \\
\hline G8 & $23,13 r$ & $25,74 j$ & $306,47 \mathrm{~b}-\mathrm{e}$ & $2,55 \mathrm{hi}$ \\
\hline G9 & $48,70 \mathrm{~h}$ & $30,18 \mathrm{gh}$ & $305,39 c-g$ & $2,76 f g h$ \\
\hline G10 & $56,52 d$ & $32,03 f g$ & 308,09a-d & $2,40 \mathrm{ij}$ \\
\hline G11 & $29,71 p$ & $31,66 f g$ & $306,74 b-e$ & $4,69 \mathrm{a}$ \\
\hline G12 & $39,86 \mathrm{~lm}$ & $25,74 j$ & $306,47 \mathrm{~b}-\mathrm{e}$ & $2,26 \mathrm{j}$ \\
\hline G13 & $43,48 \mathrm{ij}$ & $47,59 b$ & $307,28 \mathrm{bcd}$ & $4,07 \mathrm{~b}$ \\
\hline G14 & $42,03 \mathrm{jk}$ & 28,70hi & $306,20 b-f$ & $3,19 \mathrm{e}$ \\
\hline G15 & $34,78 \mathrm{n}$ & $46,85 b$ & $309,45 a b$ & $3,95 b c$ \\
\hline G16 & 32,61 o & $57,22 a$ & $304,04 f g h$ & $1,11 \mathrm{~m}$ \\
\hline G17 & $44,20 \mathrm{i}$ & $26,48 i j$ & $308,36 a b c$ & $3,64 d$ \\
\hline G18 & $58,70 \mathrm{bc}$ & $22,40 \mathrm{k}$ & $298,09 \mathrm{i}$ & $1,19 \mathrm{~lm}$ \\
\hline G19 & $54,35 \mathrm{ef}$ & $37,96 \mathrm{c}$ & $310,80 \mathrm{a}$ & $1,55 \mathrm{k}$ \\
\hline G20 & $60,14 \mathrm{ab}$ & $36,85 \mathrm{~cd}$ & $307,55 \mathrm{bcd}$ & $3,93 \mathrm{bc}$ \\
\hline G21 & $57,25 \mathrm{~cd}$ & 14,631 & $304,85 \mathrm{~d}-\mathrm{g}$ & $3,82 \mathrm{~cd}$ \\
\hline G22 & $41,30 \mathrm{kl}$ & 28,33hi & 279,721 & $1,35 \mathrm{kl}$ \\
\hline Mean & 46,41 & 31,12 & 301,87 & 2,63 \\
\hline
\end{tabular}

Different lower case letters show statistically significant differences between genotypes in column $(p<0.05)$

In the study, the highest value in \% antioxidant activity was the $\mathrm{G} 2$ genotype with $61.59 \%$, and the G20 genotype took the second place with $60.14 \%$. The lowest value was G8 genotype with $23.13 \%$. The lowest and highest values in total flavonoid values were between $14.63 \mathrm{mg} \mathrm{QE} / 100 \mathrm{~g}$ (G21 genotype) and 57.22 $\mathrm{mg} \mathrm{QE} / 100 \mathrm{~g}$ (G16 genotype), while the average total flavonoid value was determined as $31.12 \mathrm{mg}$ QE/100 g. 10 genotypes (G2, G3, G6, G10, G11, G13, G15, G16, G19, G20) of the 22 different hawthorn genotypes used in the study showed flavonoid content above the average value. In a previous study, the total amount of flavonoids in different hawthorn genotypes was determined as 78.2 and $272.6 \mathrm{mg} / 100 \mathrm{~g}$ in terms of catechins [38]. The variation of genotypes in total phenolic content in the study ranged from $277.28 \mathrm{mg} \mathrm{GAE} / 100 \mathrm{~g}$ to $310.80 \mathrm{mg} \mathrm{GAE} / 100 \mathrm{~g}$. The lowest value was G3 genotype, and the highest value was $\mathrm{G} 19$ genotype. It was determined that the genotypes included in the study had an average total phenolic content of $300 \mathrm{mg} \mathrm{GAE} / 100 \mathrm{~g}$. In a study, it was reported that the phenolic content of different hawthorn genotypes ranged from 21.19 to $69.12 \mathrm{mg} \mathrm{GAE} / \mathrm{g}$ [39]. In the current study, the G1 genotype had the lowest value with $0.85 \mathrm{mg}$ cyn-3-gluc $/ 100 \mathrm{~g}$, and the $\mathrm{G} 11$ genotype with $4.69 \mathrm{mg}$ cyn-3-gluc/100 had the highest value among the total monomeric anthocyanin values of the genotypes. Salmanian et al. [40] 
determined the total anthocyanin value in hawthorn fruit as $1.94 \mathrm{mg} \mathrm{CE} \mathrm{g/l.} \mathrm{In} \mathrm{general,} \mathrm{the} \mathrm{results}$ obtained from the study are like the studies in the literature. The reason for the differences may be the differences in the genetic material used in the study as well as the differences in the methods used.

\section{Principal Component Analysis (PCA) of Morphological and Biochemical Characteristics}

Principal component analysis values based on morphological and biochemical data of hawthorn genotypes are given in Table 4. According to principal component analysis, the first three components can explain most of the total variation (72.16\%). The first (PC1), second (PC2) and third (PC3) principal components represent $42.14 \%, 20.40 \%$ and $9.62 \%$ of the total variance, respectively. The contribution rates of morphological and biochemical properties to the first three main components differ. Among the basic components, the highest contribution to PC1 is made mainly by fruit weight, fruit width, fruit length, total phenolic substance content, flesh/stone ratio and petiole thickness. Leaf length, leaf width, stem length and total flavonoid properties made the highest contribution to PC2, while SSC, stone weight and petiole length properties made the highest contribution to PC3.

The graph of the positions corresponding to the correlation values of the hawthorn genotypes is given in Figure 2. In the decomposition made according to the first two basic components, genotypes belonging to the species were grouped within themselves in general terms. However, although they are different species according to their morphological and biochemical characteristics, G16 genotype was clustered with $C$. azarolus var. dentate species and G20 genotype was clustered with $C$. monogyna var. species. We can show the effect of the environment on morphological features as the reason for this difference. Our finding of the cumulative variance value for the first two components was similar to that of Moghadam et al. [41] and Olvera et al. [42] results, Su et al. [43] results was found to be higher. Principal component analysis reduces complex data with a small number of variables by reducing the number of associated variables. The high PC1, PC2 and PC3 variance values obtained from the study results show that the observed traits are successful in classifying the hawthorn genotypes.

Tablo 4. Principal component analysis and contribution ration based on morphological and biochemical data of hawthorn genotypes 


\begin{tabular}{lcccccc}
\hline Parameters & PC1 & \% Contribution & PC2 & \% Contribution & PC3 & \% Contribution \\
\hline Fruit Width & 0.3766 & 14.18 & -0.0146 & 0.02 & 0.1348 & 1.81 \\
Fruit Length & 0.3660 & 13.39 & 0.0513 & 0.26 & 0.0517 & 0.26 \\
Fruit Wight & 0.3861 & 14.90 & -0.1108 & 1.22 & 0.1577 & 2.48 \\
Stone Wight & -0.1087 & 1.18 & 0.3155 & 9.95 & 0.4903 & 24.03 \\
Flesh/Stone & 0.3574 & 12.77 & -0.2001 & 4.00 & -0.1267 & 1.60 \\
Soluble Solid Content & -0.0124 & 0.01 & 0.1982 & 3.92 & 0.5041 & 25.41 \\
Leaf Length & 0.1091 & 1.19 & 0.4608 & 21.23 & -0.2620 & 6.86 \\
Leaf Width & 0.1446 & 2.09 & 0.4592 & 21.08 & -0.2653 & 7.03 \\
Petiole Length & -0.1423 & 2.02 & 0.4090 & 16.72 & -0.3925 & 15.40 \\
Petiole Thickness & 0.3246 & 10.53 & 0.1576 & 2.48 & -0.1170 & 1.36 \\
Total Phenolics Content & -0.3634 & 13.20 & 0.0004 & 0.00 & -0.0311 & 0.09 \\
Total Monomeric Anthocyanin & -0.3151 & 9.92 & 0.0641 & 0.41 & 0.1087 & 1.18 \\
Total Flavonoids Content & 0.0201 & 0.04 & -0.3447 & 11.87 & -0.2569 & 6.59 \\
DPPH antioxidant activity & 0.2130 & 4.53 & 0.2604 & 6.78 & 0.2413 & 5.82 \\
Eigen Value & 5.90 & & 2.86 & & 1.35 & \\
Variance (\%) & 42.14 & & 20.40 & & 9.62 & 72.16 \\
Cumulative Variance (\%) & 42.14 & & 62.54 & & & \\
\hline
\end{tabular}

\section{ISSR Data}

ISSR marker analysis results on hawthorn genotypes are presented in Table 5. As seen in the table, 101 bands were obtained from 13 different ISSR primers. While 76 of these bands were polymorphic, the average polymorphism rate was determined as $75.24 \%$. While the number of scoreable bands varying between 4 and 13 were obtained from the primers, the average number of scoreable bands per primer was determined as 7.76. The (TCC)5RY primer produced a completely monomorphic band, and the percentage of polymorphism related to this was the lowest $(0 \%)$ in this primer. The highest value in terms of polymorphic band numbers is 10 and these bands were obtained from HVH(TCC)7, (CA)6AC and (CAA)6 primers. In addition, all bands obtained from primer VHV(GTG)7 and (AGC) $6 \mathrm{G}$ were determined as polymorphic. In the study, the average number of polymorphic bands per primer is 5.84 . To determine the genetic relationship in hawthorn species, studies were carried out using different marker systems. Among these studies, in a study using the SSR marker system, scoreable bands ranging from 2 to 21 were obtained from the primers. [44]. In another study, the average number of bands per marker was determined as 8.53 in ISSR analysis in hawthorn genotypes [45]. A total of 79 scoreable bands were obtained from 6 different ISSR primers used in the study carried out to determine genetic variation in 5 different hawthorn species grown in Iran, and the average polymorphism rate was determined as $89.9 \%$, 71 of these bands are polymorphic [46].

Table 5. Sequence and polymorphism information of ISSR primers 


\begin{tabular}{lcccc}
\hline Primers & Sequence $\left(5^{\prime}>3^{\prime}\right)$ & T.B.N & P.B.N & P.R (\%) \\
\hline$(\mathrm{AGC})_{6} \mathrm{G}$ & AGCAGCAGCAGCAGCAGCG & 6 & 6 & 100 \\
$(\mathrm{CAC})_{3} \mathrm{GC}$ & CACCACCACGC & 8 & 7 & 87,5 \\
$(\mathrm{CA})_{6} \mathrm{AC}$ & CACACACACACAAC & 13 & 10 & 76,92 \\
$(\mathrm{AG})_{8} \mathrm{~T}$ & AGAGAGAGAGAGAGAGT & 4 & 1 & 25 \\
$(\mathrm{CT})_{8} \mathrm{TG}$ & CTCTCTCTCTCTCTCTG & 9 & 8 & 88,88 \\
$(\mathrm{TCC})_{5} \mathrm{RY}$ & TCCTCCTCCTCCTCCRY & 6 & 0 & 0 \\
$(\mathrm{CAA})_{6}$ & CAACAACAACAACAACAA & 12 & 10 & $\mathbf{8 3 , 3 3}$ \\
$(\mathrm{GACA})_{4}$ & GACAGACAGACAGACA & 4 & 3 & 75 \\
$\mathrm{VHV}(\mathrm{GTG})_{7}$ & VHVGTGGTGGTGGTGGTGGTGGTG & 9 & 9 & 100 \\
$\mathrm{BDB}(\mathrm{CA})_{7} \mathrm{C}$ & BDBCACACACACACACAC & 6 & 2 & 33,33 \\
$(\mathrm{GA})_{8} \mathrm{YG}$ & GAGAGAGAGAGAGAGAYG & 5 & 4 & 80 \\
$\mathrm{DBDA}(\mathrm{CA})_{7}$ & DBDACACACACACACACA & 8 & 6 & $\mathbf{7 5}$ \\
$\mathrm{HVH}(\mathrm{TCC})_{7}$ & HVHTCCTCCTCCTCCTCCTCCTCC & 11 & 10 & 90,90 \\
\hline Mean & - & $\mathbf{7 , 7 6}$ & $\mathbf{5 , 8 4}$ & $\mathbf{7 5 , 2 4}$ \\
\hline Total & - & $\mathbf{1 0 1}$ & $\mathbf{7 6}$ & - \\
\hline
\end{tabular}

T.B.N: Total Bant Number, P.B.N: Polymorphic Band Number, P.R: Polymorphism Rate

As a result of the study, the similarity index of 22 hawthorn genotypes in the dendrogram created using the UPGMA method varied between 0.71 and 0.88 (Figure 3). In the dendrogram, 2 main groups were formed among the genotypes, while only $\mathrm{G} 5$ was in group $\mathrm{A}$, all other genotypes used in the study were in group B. In the dendrogram, group B is divided into 2 subgroups, and there is only G12 in the B-I subgroup. In the study, the genetically closest individuals were the G9 genotype and the G16 genotype with a similarity index of 0.88 . In addition, while genotypes of the same species were generally grouped together in the dendrogram, some genotypes were distributed independently of the species. Gene exchange that occurs with foreign pollination and the targeting of the ISSR marker system to random regions in the genome can be shown as the cause of this difference [47]. In a study, 92 different genotypes of the Crataegus songorica species were used and it was reported that the similarity index values in the genotypes varied between 0.53 and 0.87 in the ISSR marker analysis [48].

In our current study, 22 different hawthorn genotypes belonging to 3 different species were used, and it was aimed to determine genetic variation between genotypes by molecular, morphological, and phytochemical analyzes. Wide variations were detected between genotypes in all the examined marker systems, and G3 genotype produced better results than other genotypes in terms of fruit characteristics. In phytochemical analyzes, it was determined that phenolic compounds which are very important for human health, are intensely present in hawthorn genotypes. On the other hand, in the molecular marker analyzes we conducted, genotypes were generally grouped according to their species, and 2 main groups were formed in the dendrogram. As a result of the study, molecular and morphological data did not fully overlap. In molecular studies, the G9 and G16 with a similarity ratio of 0.88 were determined as the closest 
individuals to each other. Although these two individuals showed similarity in molecular analysis, some differences emerged in morphological analysis. This situation can be attributed to the effect of the environment on morphological features and gene exchanges caused by foreign pollination and fertilization that have occurred over the years. While it is determined by the results of the study that ISSR markers are among the marker systems that can be used to determine genetic diversity among genotypes, it is thought that all the data obtained can guide researchers in the protection and development of this species.

\section{Declarations}

\section{Funding}

There is no funding for this study.

\section{Conflicts of Interest}

The authors declare that author have no known competing financial interests or personal relationships that could have appeared to influence the work reported in this paper.

\section{Consent to participate}

Authors mentioned in the manuscript have agreed for authorship, read and approved the manuscript.

\section{Consent to Publish (Ethics)}

Authors give the consent for the publication of identifiable details, which can include photograph(s)/tables and/or details within the text to be published in the "Molecular Biology Reports" Journal.

\section{References}

1. Ercisli S (2004) A short review of the fruit germplasm resources of Turkey. Genetic Resour Crop Evol $51: 419-435$

2. Donmez AA (2004) Nomenclatural, taxonomic and biogeographic novelties in the Turkish Crataegus L. (Rosaceae-Maleae) taxa. Adansonia 36(2):245-253

3. Kean JM (2009) Potential distribution of hawthorn in New Zealand. New Zealand Plant Protection 62:387-392

4. Nazhand A, Lucarini M, Durazzo A, Zaccardelli M, Cristarella S, Souto SB, Santini A (2020) Hawthorn (Crataegus spp.): an updated overview on its beneficial properties. Forests 11(5):564

5. Karadeniz T (2004) Şifalı Meyveler, K.T.Ü. Ordu Ziraat Fakültesi. Bahçe Bitkileri Bölümü, s 34-36, Ordu 
6. Balta MF, Karakaya O, Kaptan Ekici G (2015) Çorum®da yetişen alıçların (Crataegus spp.) fiziksel özellikleri. Ordu Üniv Bil Tek Derg 5(2):35-41

7. Bektaş M, Bükücü ŞB, Özcan A, Sütyemez M (2017) Akçadağ ve Hekimhan İlçelerinde Yetişen Alıç (Crataeugus spp.) Genotiplerinin Bitki ve Pomolojik Özellikleri. Türk Tarım ve Doğa. Bilimleri Dergisi 4(4):484-490

8. Muradoglu F, Gursoy S, Yildiz K (2019) Quantification analysis of biochemical and phenolic composition in Hawthorn (Crataegus spp.) Fruits. Erwerbs-Obstbau 61(2):189-194

9. Yilmaz KU, Yanar M, Ercisli S, Sahiner H, Taksin T, Zengin Y (2010) Genetic relationships among some hawthorn (Crataegus spp.) species and genotypes. Biochem Gen 48:873-878

10. Corlett RT (2016) Plant diversity in a changing world: status, trends, and conservation needs. Plant diversity 38(1):10-16

11. Koornneef M, Alonso-Blanco C, Vreugdenhil D (2004) Naturally occurring genetic variation in Arabidopsis thaliana. Annu Rev Plant Biol 55:141-172

12. Uzun A, Coşkun OF, Yaman M, Pınar H, Paris K (2017) Orta Anadolu'dan Selekte Edilen Ceviz (Juglans regia L.) Genotipleri Arasındaki Genetik ilişkilerin SRAP Markırları ile Belirlenmesi. Alatarım 16(1):2634

13. Pinar H, Ercisli S, Bircan M, Unlu M, Uzun A, Yilmaz KU, Yaman M (2017) Morphological, Molecular, and Self-(In) Compatibility Characteristics of New Promising Apricot Genotypes

14. Karık Ü, Nadeem MA, Habyarimana E, Ercişli S, Yıldız M, Yılmaz A, Yang SH, Chung G, Baloch FS (2019) Exploring the genetic diversity and population structure of Turkish Laurel germplasm by the iPBS-retrotransposon marker system. Agronomy-Basel 9:1-14

15. Kamara MM, Rehan M, Ibrahim KM, Alsohim AS, Elsharkawy MM, Kheir A, El-Esawi MA (2020) Genetic diversity and combining ability of white maize inbred lines under different plant densities. Plants 9(9):1140

16. Barut M, Nadeem MA, KARAKÖY T, BALOCH FS (2020) DNA fingerprinting and genetic diversity analysis of world quinoa germplasm using iPBS-retrotransposon marker system. Turkish Journal of Agriculture and Forestry 44(5):479-491

17. Yildiz M, Kocak M, Nadeem MA, Cavagnaro P, Barboza K, Baloch FS, Keleş D (2020) Genetic diversity analysis in the Turkish pepper germplasm using iPBS retrotransposonbased markers. Turkish Journal of Agriculture and Forestry 44(1):1-14

18. Swarup S, Cargill EJ, Crosby K, Flagel L, Kniskern J, Glenn KC (2021) Genetic diversity is indispensable for plant breeding to improve crops. Crop Sci 61(2):839-852

19. Nadeem MA, Nawaz MA, Shahid MQ, Doğan Y, Comertpay G, Yıldız M, Baloch FS (2018) DNA molecular markers in plant breeding: current status and recent advancements in genomic selection and genome editing. Biotechnology \& Biotechnological Equipment 32(2):261-285

20. Yaman M (2021) Evaluation of genetic diversity by morphological, biochemical and molecular markers in sour cherry genotypes. Mol Biol Rep (2021). https://doi.org/10.1007/s11033-021-06941-6 
21. Giusti MM, Wrolstad RE (2001) Anthocyanins: characterization and measurement with UV-visible spectroscopy.. In: In: Wrolstald RE (ed) Current Protocols in Food Analytical Chemistry. John Wiley and Sons, New York, pp 1-13

22. Chang CC, Yang MH, Wen HM, Chern JC (2002) Estimation of total flavonoid content in propolis by two complementary colorimetric methods. Journal of food and drug analysis 10(3):178-182

23. Brand-Williams W, Cuvelier ME, Berset CLWT (1995) Use of a free radical method to evaluate antioxidant activity. LWT-Food Science and Technology 28:25-30

24. Garcia EJ, Oldoni TLC, Alencar SMD, Reis A, Loguercio AD, Grande RHM (2012) Antioxidant activity by DPPH assay of potential solutions to be applied on bleached teeth. Braz Dent J 23:22-27

25. Singleton VL, Orthofer R, Lamuela-Raventós RM (1999) Analysis of total phenols and other oxidation substrates and antioxidants by means of folin-ciocalteu reagent. Methods Enzymol 299:152-178

26. Doyle JJ, Doyle JL (1990) Isolation of plant DNA from fresh tissue. Focus 12(13):39-40

27. Rohlf FJ (2000) NTSYS-pc: numerical taxonomy and multivariate analysis system, version 2.1. Exeter Software, Setauket, New York

28. Sneath PHA, Sokal RR (1973) Numerical Taxonomy; Freeman: San Francisco, CA, USA

29. Balasooriya BLWK, Samson R, Mbikwa F, Boeckx P, Van Meirvenne M (2009) Biomonitoring of urban habitat quality by anatomical and chemical leaf characteristics. Environ Exp Bot 65(2-3):386-394

30. Erfani-Moghadam J, Mozafari M, Fazeli A (2016) Genetic variation of some hawthorn species based on phenotypic characteristics and RAPD marker. Biotechnology \& Biotechnological Equipment 30(2):247-253

31. Kuhn T, Jancsó B, Ruprecht E (2020) Hawthorn (Crataegus L.) taxa and their hybrids in north-western Romania: a recommendation for national identification keys based on morphometric analyses. Contributii Botanice, (55)

32. Moghadam JE, Kheiralipour K (2015) Physical and nutritional properties of hawthorn fruit (Crataegus pontica L.).Agricultural Engineering International: CIGR Journal, 17(1)

33. Dursun A, Caliskan O, Guler Z, Bayazit S, Turkmen D, Gunduz K (2021) Effect of harvest maturity on volatile compounds profiling and eating quality of hawthorn (Crataegus azarolus L.) fruit. Sci Hort 288:110398

34. Gurlen A, Gundogdu M, Ozer G, Ercisli S, Duralija B (2020) Primary, Secondary Metabolites and Molecular Characterization of Hawthorn (Crataegus spp.) Genotypes. Agronomy 10(11):1731

35. Aglar E, Sumbul A, Karakaya O, Ozturk B (2020) Determination Of The Quality Characteristics Of Naturally Growing Hawthorn In Suşehri. Acta Scientiarum Polonorum-Hortorum Cultus 19(1):61-70

36. Yanar, M., Ercisli, S., Yilmaz, K. U., Sahiner, H., Taskin, T., Zengin, Y., ... Celik,F. (2011). Morphological and chemical diversity among hawthorn (Crataegus spp.) genotypes from Turkey. Scientific Research and Essays, 6(1), 35-38

37. Ozderin S, Fakir H (2015) Some botanical properties of hawthorn (Crataegus L. spp.) taxa natural distributed in the western Anatolia part of Turkey. Int J Agric Innov and Res 4:567-572 
38. Güzel N (2021) Alıç: biyoaktif bileşenlerin termosonikasyon ile ekstraksiyonu ve fiziko-kimyasal özelliklerinin değerlendirilmesi. Gıda 46(4):939-948

39. Alirezalu, A., Ahmadi, N., Salehi, P., Sonboli, A., Alirezalu, K., Mousavi Khaneghah,A., ... Lorenzo, J. M. (2020). Physicochemical characterization, antioxidant activity,and phenolic compounds of hawthorn (Crataegus spp.) fruits species for potential use in food applications. Foods, 9(4), 436

40. Salmanian SSMA, Sadeghi Mahoonak AR, Alami M, Ghorbani M (2014) Phenolic content, antiradical, antioxidant, and antibacterial properties of hawthorn (Crataegus elbursensis) seed and pulp extract. Journal of Agricultural Science and Technology 16(2):343-354

41. Moghadam JE, Mozafari M, Fazeli A (2016) Genetic variation of some hawthorn species based on phenotypic characteristics and RAPD marker. Biotechnology \& Biotechnological Equipment 30(2):247-253

42. Olvera MB, Angel RN, Urbano B, Andres FG (2018) Analysis of the biodiversity of hawthorn (Crataegus spp.) from the morphological, molecular, and ethnobotanical approaches, and implications for genetic resource conservation in scenery of increasing cultivation: the case of Mexico. Genet Resour Crop Evol (2018) 65:897-916

43. Su K, Guo YS, Wang G, Zhao YH, Dong WX (2015) Genetic diversity analysis of fruit characteristics of hawthorn germplasm. Genet Mol Res 14(4):16012-16017

44. Guney M, Kafkas S, Keles H, Aras S, Ercisli S (2018) Characterization of hawthorn (Crataegus spp.) genotypes by SSR markers. Physiology and Molecular Biology of Plants 24(6):1221-1230

45. Ghanbari A, Estaji A, Fahim S, Jamali M (2019) Assessment of genetic diversity among Crataegus genotypes by Application of ISSR markers in Ardabil province. Journal of Plant Molecular Breeding $7(1): 77-83$

46. Beigmohamadi M, Rahmani F, Mirzaei L (2021) Study of Genetic Diversity Among Crataegus Species (Hawthorn) Using ISSR Markers in Northwestern of Iran. Pharmaceutical and Biomedical Research

47. Yorgancılar M, Yakışır E, Erkoyuncu MT (2015) Moleküler Markörlerin Bitki Islahında Kullanımı. Bahri Dağdaş Bitkisel Araştırma Dergisi 4(2):1-12

48. Sheng, F., Chen, S. Y., Jia, T. I. A. N., Peng, L. I., Xue, Q. I. N., Lei, W. A. N.G., ... Jiang, L. I. (2017). Morphological and ISSR molecular markers reveal genetic diversity of wild hawthorns (Crataegus songorica K. Koch.) in Xinjiang, China. Journal of integrative agriculture, 16(11), 2482-2495

\section{Figures}




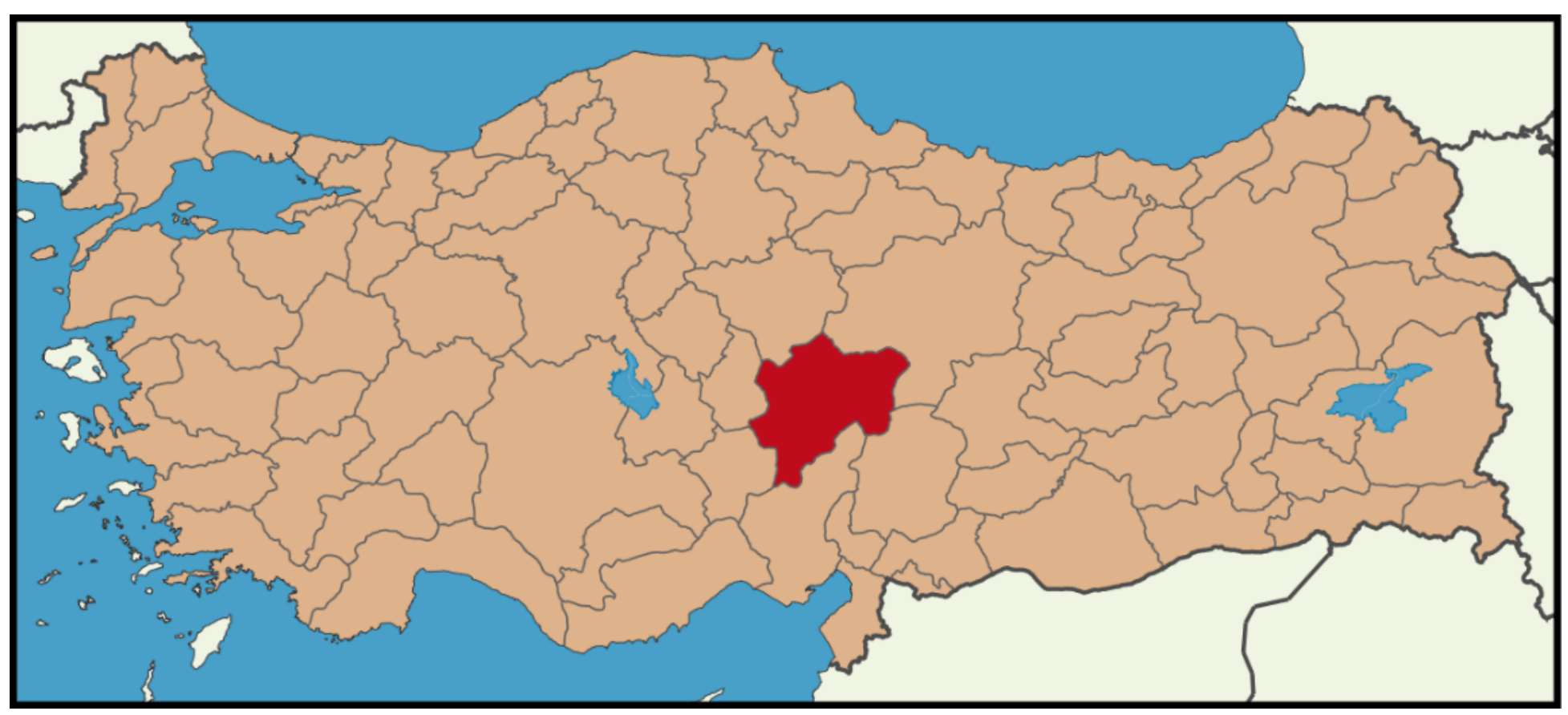

Figure 1

Location of Kayseri province on the map of Turkey (source: wikipedia.org)

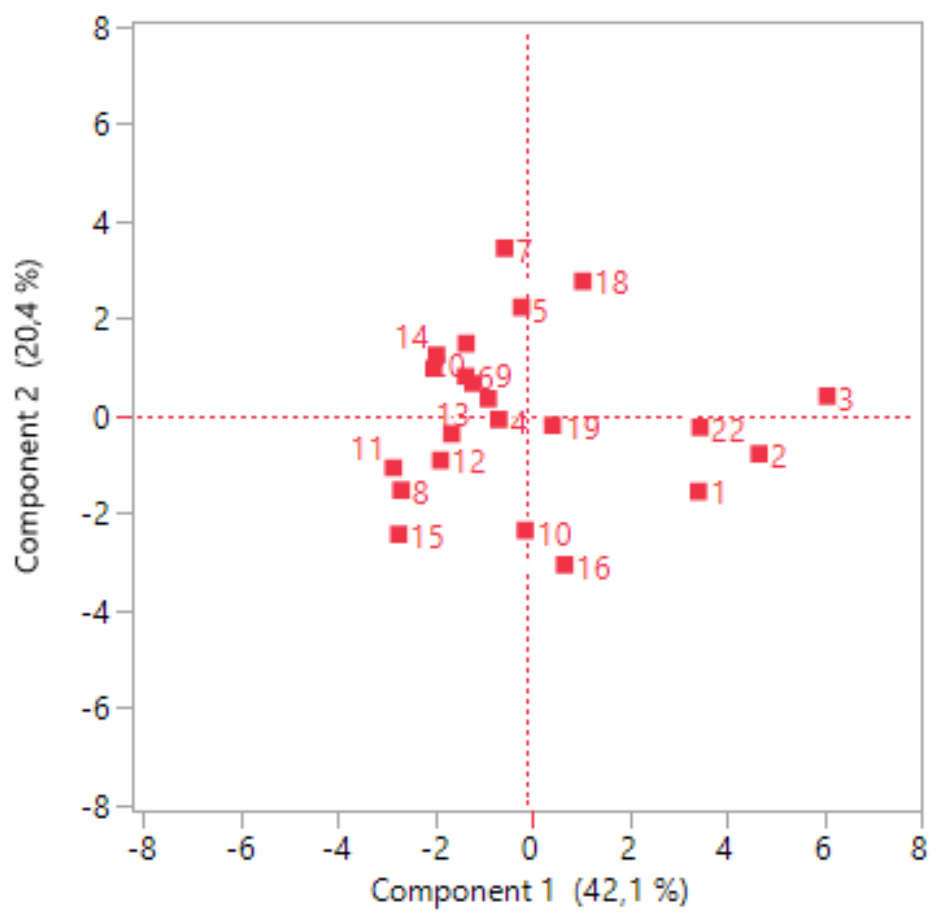

Figure 2

Principal Component Analysis plot estimated of variables observed on hawthorn genotypes 


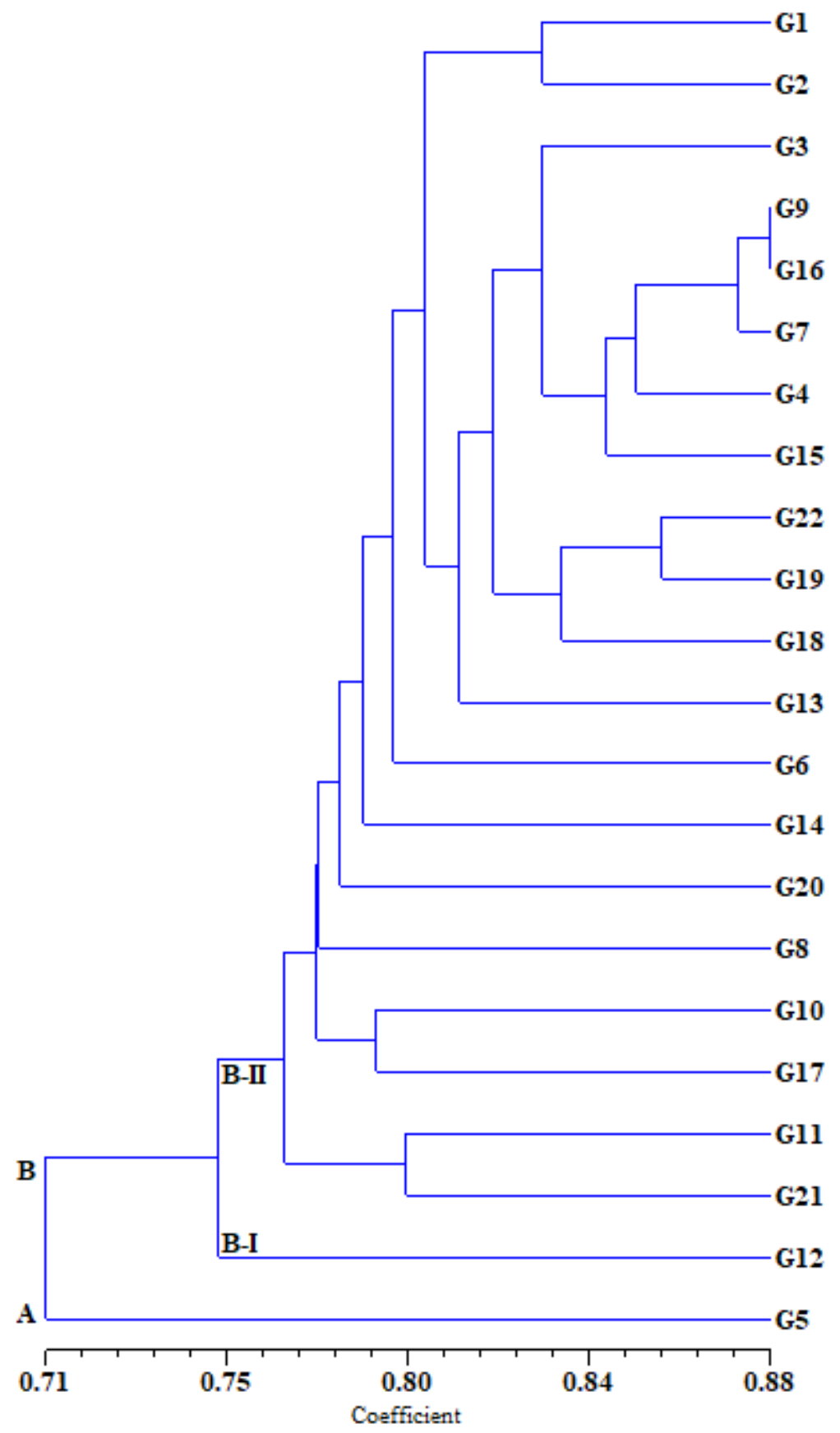

Figure 3

UPGMA dendrogram of hawthorn genotypes 